\title{
National market of diagnostic tests and test systems
}

\author{
T. S. Brytanova ${ }^{\star A}{ }^{* B, D}$, A. V. Samko iD $C, E$, Ye. H. Knysh DE,F
}

Zaporizhzhia State Medical University, Ukraine

A - research concept and design; B - collection and/or assembly of data; C - data analysis and interpretation; D - writing the article; $\mathrm{E}$ - critical revision of the article; $\mathrm{F}$ - final approval of the article

The aim of the work was to analyze the market of diagnostic tests and test systems that are in circulation in Ukraine.

Materials and methods. To achieve this goal, electronic and paper official sources of information were used, as well as pharmacy websites. The search, analytical, systematic, comparative and statistical methods and methods of mathematical and logical analysis were used in the work.

Results. Analysis of the modern market of diagnostic tests and test systems were allowed to establish the range and brand structure (90 manufacturers). The vast majority of them are outside Ukraine (85.5\%). Among foreign producers, the largest importer is China (19.5\%). In the course of work to determine the level of competition between manufacturers of similar groups of tests and test systems set the coefficient of tension. To determine the level of availability, price liquidity and solvency adequacy ratios were calculated.

Conclusions. The Ukrainian market of diagnostic tests and test systems was studied. It was established that the company structure consists of 90 manufacturers and 20 countries. The vast majority of products come from importing countries $(85.5 \%)$, where the leader is China (19.5\%). Analysis of competitiveness showed that the greatest competition was observed among companies that produce tests to determine pregnancy, glucose, ketones, nitrites and protein in the blood and urine (Kvi=0.96), and there was no test manufacturers for sperm testing $(\mathrm{K} v i=0)$. The calculated price liquidity and adequacy of solvency ratios indicate high price competition and low availability for some groups of diagnostic tests and test systems.

Key words: pharmaceutical market, diagnostic tests, analysis, price situation.

Current issues in pharmacy and medicine: science and practice 2020; 13 (3), 388-393

Національний ринок діагностичних тестів і тест-систем

Т. С. Британова, А. В. Самко, Є. Г. Книш

Мета роботи - аналіз ринку діагностичних тестів і тест-систем, що перебувають в обігу в Україні.

Матеріали та методи. Використали електронні та паперові офіційні джерела інформації, а також інтернет-сайти аптек. Застосовували пошуковий, аналітичний, систематичний, порівняльний і статистичний методи та методи математичного, логічного аналізів.

Результати. Аналіз сучасного ринку діагностичних тестів і тест-систем дав можливість встановити асортиментну та фрірмову (90 фірм-виробників) структури. Більшість із них знаходяться за межами України (85,5%). Серед іноземних виробників найбільший імпортер - КНР (19,5 \%). Під час роботи для визначення рівня конкуренції між виробниками аналогічних груп тестів і тест-систем встановили коефіцієнт напруженості. Для визначення рівня доступності розрахували коефіцієнти ліквідності ціни та адекватності платоспроможності.

Висновки. Досліджено вітчизняний ринок діагностичних тестів і тест-систем. Встановлено, що фірмова структура складається 3 90 фірм-виробників та 20 країн світу. Переважна більшість продукції надходить від країн-імпортерів (85,5 \%), де лідером є Китай (19,5 \%). Аналіз конкурентоспроможності показав, що найбільша конкуренція - серед компаній, які випускають тести для визначення вагітності, рівня глюкози, кетонів, нітритів, білка у крові та сечі (Kvi = 0,96), у виробників відсутні тести для дослідження сперми (Kvi = 0). Розраховані коефіцієнти ліквідності ціни та адекватності платоспроможності показують високу цінову конкуренцію та низьку доступність для деяких груп діагностичних тестів і тест-систем.

Ключові слова: фармацевтичний ринок, діагностичні тести, аналіз, цінова кон'юнктура.

Актуальні питання фрармацевтичної і медичної науки та практики. 2020. Т. 13, № 3(34). С. 388-393

ARTICLE

INFO

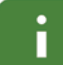

http:l/pharmed.

zsmu.edu.ualarticle/

view/216217
UDC 339.13:615.4:616-07](477)

DOI: $10.14739 / 2409-2932.2020 .3 .216217$

Current issues in pharmacy and medicine: science and practice 2020; 13 (3), 388-393

Key words: pharmaceutical market, diagnostic tests, analysis, price situation

*E-mail: goculyats@gmail.com

Received: 01.09.2020 // Revised: 08.09.2020 // Accepted: 10.09.2020 


\title{
Национальный рынок диагностических тестов и тест-систем
}

\author{
Т. С. Британова, А. В. Самко, Е. Г. Кныш
}

Цель работы - анализ рынка диагностических тестов и тест-систем, которые находятся в обороте в Украине.

Материалы и методы. Использованы электронные, бумажные официальные источники информации, интернет-сайты аптек. В работе применяли поисковый, аналитический, систематический, сравнительный и статистический методы и методы математического, логического анализа.

Результаты. Анализ современного рынка диагностических тестов и тест-систем позволил установить ассортиментную и фирменную (90 фирм-производителей) структуры. Большинство из них находятся за пределами Украины (85,5 \%). Среди иностранных производителей крупнейшим импортером является КНР (19,5\%).

В ходе работы для определения уровня конкуренции между производителями аналогичных групп тестов и тест-систем установили коэффициент напряженности. Для определения уровня доступности рассчитали коэффициенты ликвидности цен и адекватности платежеспособности.

Выводы. Исследован отечественный рынок диагностических тестов и тест-систем. Установлено, что фирменная структура состоит из 90 фирм-производителей и 20 стран мира. Подавляющее большинство продукции поступает от стран-импортеров $(85,5 \%)$, где лидером является КНР $(19,5 \%)$.

Анализ конкурентоспособности показал, что наибольшая конкуренция - среди компаний, которые выпускают тесты для определения беременности, уровня глюкозы, кетонов, нитритов, белка в крови и моче (Kvi = 0,96), у производителей отсутствуют тесты для исследования спермы (Kvi = 0). Рассчитанные коэффрициенты ликвидности цены и адекватности платежеспособности свидетельствуют о высокой ценовой конкуренции и низкой доступности для некоторых групп диагностических тестов и тест-систем.

Ключевые слова: фрармацевтический рынок, диагностические тесты, анализ, ценовая конъюнктура.

Актуальные вопросы фрармацевтической и медицинской науки и практики. 2020. Т. 13, № 3(34). С. 388-393

Diagnostic tests and test systems can be valuable aids for diagnosis, but as screening tools to detect latent diseases in asymptomatic individuals, their usefulness is limited. The value of the test as a diagnostic tool depends on its sensitivity and specificity.

It should be noted that modern tests can detect a fairly large list of diseases. In particular, these are: HIV infection, syphilis, gonorrhea, chlamydia, hepatitis $\mathrm{C}$, hepatitis $\mathrm{B}$, tuberculosis, and others. Tests for cancer markers are also available, which can indirectly confirm the presence of prostate and bowel cancer. Some of them detect prostate-specific antigen in the blood, others determine the presence of internal bleeding, which may be a sign of bowel cancer. One of the newest tests are those that can confirm myocardial infarction, or rather the presence in the blood of a specific protein troponin, which appears in severe damage to the heart muscle.

Because in many cases the diagnosis of diseases is not desirable for the patient in treatment and prevention facilities, rapid diagnostic tests are a successful development in the field of medicine. Thus, availability and ease of use, anonymity, low cost, and speed are excellent for the preventive diagnosis of a number of diseases. This is especially important if there is a possibility of infection - such a rapid examination can be the first step in the diagnosis [1].

\section{Aim}

The purpose of the research is to analyze the market of diagnostic tests and test systems that are in circulation in Ukraine.

\section{Materials and methods}

Electronic and paper official sources of information and pharmacy websites were used to achieve this goal. The search, analytical, systematic, comparative, and statistical methods, methods of mathematical and logical analysis were used in the work [2-9].

\section{Results}

In the course of the work, diagnostic tests and test systems were systematized according to the purpose and type of products. Selected on the pharmaceutical market of Ukraine were contained 45 groups and 200 assortments items from 20 countries of the world that 90 pharmaceutical companies (Fig. 1).

\section{Discussion}

Data from the State Register of Medical Equipment and Medical Devices, information on the state registration certificate for expired medical devices (as of 2019) and data from the weekly "Pharmacy" were used to analyze the company structure $[10,11]$.

Given the number of manufacturers of diagnostic tests and test systems from all countries, the rating of each country was set separately. Thus, the first place was occupied by China $(17.78 \%$ ), which supplies it was products from 16 pharmaceutical companies. The second place was occupied by the USA $(12.2 \%)$, products come from 11 pharmaceutical manufacturers. Third place was shared by Germany (10.0\%) and Korea $(10.0 \%)$. They provided the market with goods from 9 manufacturers each (Fig. 2).

The ratio between domestic and foreign companies was $1: 7$.

Taking into account the number of offers of all producing countries in the pharmaceutical market, the rating of each country was set separately (Fig. 2). To determine the level 


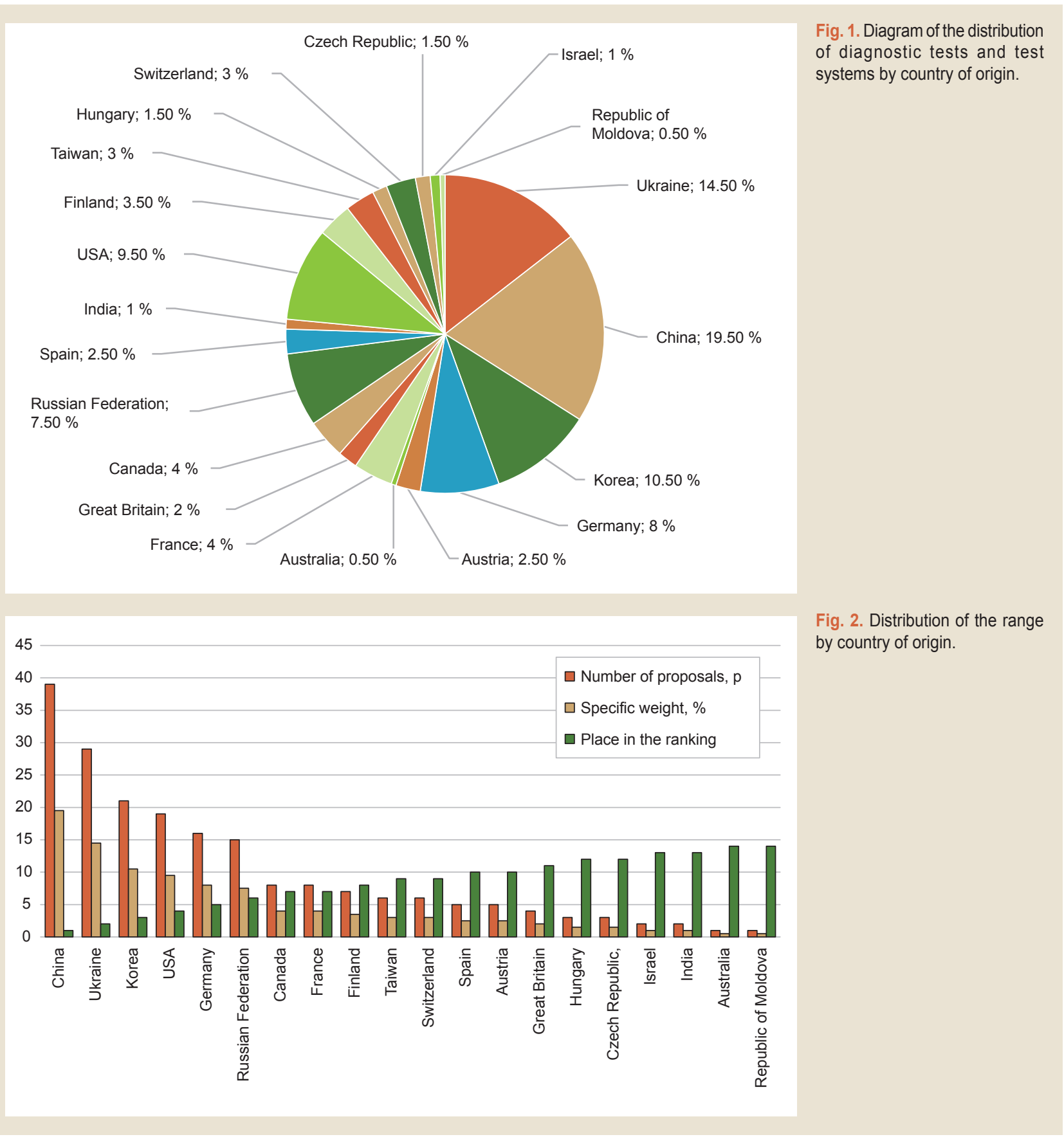

of competition between manufacturers of similar groups of diagnostic tests, the stress factor Kvi was calculated by the formula:

$\mathrm{K} v i=\frac{n-1}{n}$,

where $n$ - number of all competing counterparts of firms [12].

According to the results obtained (Table 1), the greatest competition from manufacturers of tests for pregnancy, glucose, ketones, nitrites and protein in the blood and urine $(\mathrm{K} v i=0.96)$. In second place were tests to determine ovula- tion and follicle-stimulating hormone $(\mathrm{K} v i=0.95)$. The third place was shared among tests for drugs and tests for troponin I, KK-MB, myoglobin $(\mathrm{K} v i=0.92)$.

It should also be noted that at the time of the study of diagnostic tests and test systems, the competitiveness index was equal to 0 in tests for sperm testing.

Important characteristics of diagnostic tests and test systems were the liquidity ratio and the solvency adequacy ratio. The price liquidity ratio reflects the degree of competition in the pharmaceutical market and to some extent characterizes the availability of a medical device.

This indicator was calculated as the ratio of the difference between the maximum and minimum price to the minimum 
Table 1. Indicators of the coefficient of intensity of diagnostic tests and test systems

\begin{tabular}{|c|c|c|}
\hline № & Name of test groups and test systems & Kvi \\
\hline 1. & Pregnancy test strip & 0.96 \\
\hline 2. & $\begin{array}{l}\text { Tests to determine ovulation and follicle-stimulat- } \\
\text { ing hormone }\end{array}$ & 0.95 \\
\hline 3. & Tests to determine troponin I, KK-MV, myoglobin & 0.92 \\
\hline 4. & Tests for syphilis & 0.8 \\
\hline 5. & Tests for rotavirus infection & 0.86 \\
\hline 6. & Tests to detect antibodies to H. Pylori & 0.75 \\
\hline 8. & Tests to detect adenoviral infection & 0.75 \\
\hline 9. & Tests to detect Giardia & 0.5 \\
\hline 10. & Tests to detect pathogens of influenza virus & 0.75 \\
\hline 11. & Tests for drugs & 0.92 \\
\hline 12. & Tests to detect hepatitis $A, B, C$ virus & 0.89 \\
\hline 13. & Tests for the diagnosis of acute pancreatitis & 0.67 \\
\hline 14. & Tests for the diagnosis of tuberculosis & 0.5 \\
\hline 15. & Tests for HIV 1 / HIV 2 & 0.89 \\
\hline 16. & Tests to detect nicotine in the urine & 0.5 \\
\hline 17. & Tests to detect amniotic fluid & 0.67 \\
\hline 18. & $\begin{array}{l}\text { Tests to determine the level of glucose, ketones, } \\
\text { nitrites and protein in the blood and urine }\end{array}$ & 0.96 \\
\hline 19. & $\begin{array}{l}\text { Test for detection of salmonella antigens } \\
\text { in feces }\end{array}$ & 0.5 \\
\hline 20. & Tests to determine malaria & 0.67 \\
\hline 21. & Tests to determine inflammatory processes & 0.5 \\
\hline 22. & Tests for the diagnosis of allergies & 0.67 \\
\hline 23. & Tests to determine cholesterol levels & 0.5 \\
\hline 24. & Tests for syphilis & 0.8 \\
\hline 25. & Tests for hemoglobin and transferrin in feces & 0.83 \\
\hline 26. & Tests for Denguevirus & 0.5 \\
\hline 27. & Tests to detect tumor markers & 0.83 \\
\hline 28. & Test kits for newborn screening & 0.5 \\
\hline 29. & Tests for sperm testing & 0 \\
\hline 30. & $\begin{array}{l}\text { Tests to determine the } \mathrm{pH} \text { of the vaginal environ- } \\
\text { ment }\end{array}$ & 0.5 \\
\hline 31. & Tests to determine TORCH infection & 0.67 \\
\hline
\end{tabular}

price of a medical device. The liquidity ratio was calculated by the formula:

$\mathrm{K} l i q=\frac{P \max -P \min }{P \min }$,

where Kliq - price liquidity ratio; Pmax - maximum price; Pmin - minimum price $[13,14]$.

Data from the site Tabletki.ua as of October 2019 were used for analysis [2].
The results of the analysis are presented in Table 2.

As can be seen from the Table 2, the liquidity ratio for half of the diagnostic tests and the test system was within the value of 0.5. The highest value of Cliq in Citolab K (urine) № 50 (6.12), Cito test (4.34), Cito test HCV (3.32), HIV 1/2 strip for ketones detection № 25 (2.24), Test cassette for the simultaneous detection of 5 drugs (urine) (1.38), Test cassette for the simultaneous detection of drugs (urine (1.27), Cito test $H$. pylori Ag (1.09). Non-price competition is typical for Test for determining the sex of the child (0.029), Cito Test $\mathrm{pH}$ (vaginal environment) (0.037) and Menopause Test (0.04).

It should be noted that one of the relative indicators of socio-economic accessibility of diagnostic tests and test systems was the solvency adequacy ratio, which was determined by the formula:

Ka.s. $=\frac{P}{\text { Wa.w. }} \times 100 \%$,

where Ka.s. - solvency adequacy ratio; $P$ - the average price of the drug for a certain period of time (October 2019); Wa.w. - average salary for a certain period (according to the State Statistics Service of Ukraine).

As of October 2019, the average salary was UAH 10727 $[13,15]$.

Calculated indicators of show that among the diagnostic tests and test systems more available to consumers were the Test for determination of urine $\mathrm{pH}$ № 50 (0.23), Test for determination of menopause (0.30), Test strip for ketones detection № 25 (0.33), Cito Test pH (vaginal environment) (0.50). The least available for consumers were the Test for measuring the level of cholesterol, uric acid in the blood (4.47), the Test for the determination of amniotic fluids (4.41), the Test cassette for the simultaneous detection of drugs (urine) (3.60). High values of may be due to the high cost of these products and originality in the pharmaceutical market of Ukraine.

\section{Conclusions}

The Ukrainian market of diagnostic tests and test systems was studied. It was established that the company structure consists of 90 manufacturers and 20 countries. The vast majority of products come from importing countries $(85.5 \%)$, where the leader was China (19.5\%).

Analysis of competitiveness showed that the greatest competition was observed among companies that produce tests to determine pregnancy, glucose, ketones, nitrites and protein in the blood and urine $(\mathrm{K} v i=0.96)$, and there was no test manufacturers for sperm testing $(\mathrm{K} v i=0)$.

The calculated price liquidity and adequacy of solvency ratios indicate high price competition and low availability for some groups of diagnostic tests and test systems. 
Table 2. The results of the analysis of indicators of socio-economic accessibility of diagnostic tests and test systems of the retail pharmacy network

\begin{tabular}{|c|c|c|c|c|c|c|c|}
\hline$\#$ & The name of the medical device & Manufacturer & $\begin{array}{l}\text { Retail price, } \\
\text { max, UAH }\end{array}$ & $\begin{array}{l}\text { Retail price, } \\
\text { min, UAH }\end{array}$ & Kliq & $\begin{array}{l}\text { Average retail } \\
\text { price, UAH }\end{array}$ & Ca.s. \\
\hline 1. & Cito Test Rota & Pharmasco Ltd & 91.10 & 129.10 & 0.42 & 123.94 & 1.16 \\
\hline 2. & Cito Test $H$. pylori Ag & Pharmasco Ltd & 133.13 & 278.15 & 1.09 & 184.91 & 1.72 \\
\hline 3. & Test strip for ketones detection № 25 & TOV Norma & 24.99 & 81.07 & 2.24 & 35.19 & 0.33 \\
\hline 4. & $\begin{array}{l}\text { Test cassette for the simultaneous detection } \\
\text { of } 5 \text { drugs (urine) }\end{array}$ & Alfa Scientific Designs, Inc. & 146.85 & 349.15 & 1.38 & 228.04 & 2.13 \\
\hline 5. & CitoTest Giardia & Certest Biotec S.L. & 195.5 & 173.47 & 0.12 & 182.6 & 1.70 \\
\hline 6. & Cito Test HBsAg (blood) & Pharmasco Ltd & 127.0 & 72.94 & 0.74 & 93.74 & 0.87 \\
\hline 7. & $\begin{array}{l}\text { Test cassette for the simultaneous detection } \\
\text { of drugs (urine) }\end{array}$ & Alfa Scientific Designs, Inc. & 256.80 & 583.10 & 1.27 & 385.84 & 3.60 \\
\hline 8. & Cito Test HCV (blood) & Pharmasco Ltd & 28.50 & 123.10 & 3.32 & 116.72 & 1.09 \\
\hline 9. & Cito Test FOB (feces) & Pharmasco Ltd & 95.34 & 121.35 & 0.27 & 110.11 & 1.03 \\
\hline 10. & Cito Test for H.pylori & Pharmasco Ltd & 192.53 & 226.50 & 0.18 & 226.50 & 2.11 \\
\hline 11. & Cito Test Myoglobin (blood) & Pharmasco Ltd & 264.50 & 233.29 & 0.13 & 147.40 & 1.37 \\
\hline 12. & Cito Test Troponin 1 (blood) & Pharmasco Ltd & 284.00 & 117.86 & 1.40 & 198.90 & 1.85 \\
\hline 13. & Cito Lab G №50 (urine) & Pharmasco Ltd & 149.00 & 130.71 & 0.13 & 139.85 & 1.30 \\
\hline 14. & Cito Lab 3GK (urine) №100 & Pharmasco Ltd & 336.00 & 268.93 & 0.97 & 302.46 & 2.81 \\
\hline 15. & Cito Lab 3GK (urine) №50 & Pharmasco Ltd & 149.00 & 125.06 & 0.19 & 137.30 & 1.27 \\
\hline 16. & Тест для визначення статі дитини & Intelligender & 350.00 & 340.00 & 0.03 & 345.00 & 3.21 \\
\hline 17. & Cito Test pH (vaginal environment) & Pharmasco Ltd & 55.00 & 53.00 & 0.04 & 54.00 & 0.50 \\
\hline 18. & $\begin{array}{l}\text { Test to detect antibodies to Mycobacterium } \\
\text { tuberculosis }\end{array}$ & BioTech USA & 100.00 & 89.03 & 0.12 & 94.5 & 0.88 \\
\hline 19. & Cito test Influenza A+B (nasal smear) & Pharmasco Ltd & 266.90 & 234.00 & 0.14 & 250.45 & 2.33 \\
\hline 20. & Citolab K (urine) №50 & Pharmasco Ltd & 21.21 & 151.05 & 6.12 & 133.41 & 1.24 \\
\hline 21. & Test to determine ovulation & Pharmasco Ltd & 177.70 & 139.00 & 0.27 & 158.35 & 1.47 \\
\hline 22. & Test for the determination of amniotic fluids & Oy Medix Biochemica Ab & 484.50 & 462.68 & 0.04 & 473.59 & 4.41 \\
\hline 23. & Cito Test HIV $1 / 2$ & Pharmasco Ltd & 27.26 & 147.00 & 4.39 & 107.31 & 1.00 \\
\hline 24. & Cito Test FOB-Transferrin (feces) & Pharmasco Ltd & 123.98 & 173.35 & 0.40 & 151.76 & 1.41 \\
\hline 25. & Cito lab pH (vaginal discharge) & Pharmasco Ltd & 41.27 & 69.75 & 0.69 & 51.37 & 0.48 \\
\hline 26. & Cito Test Rota-Adeno (feces) & Pharmasco Ltd & 120.00 & 237.20 & 0.98 & 192.70 & 1.80 \\
\hline 27. & CitoTest Syphilis (blood) & Pharmasco Ltd & 95.00 & 81.24 & 0.16 & 88.12 & 0.82 \\
\hline 28. & Test to determine menopause & $\begin{array}{l}\text { AXIOM Gesel Ischafffur } \\
\text { Diagnostica }\end{array}$ & 170.00 & 163.00 & 0.04 & 166.30 & 1.55 \\
\hline 29. & $\begin{array}{l}\text { Test strips to determine protein } \\
\text { in the urine }\end{array}$ & YD Diagnostics CORP. & 110.00 & 105.00 & 0.05 & 107.50 & 1.00 \\
\hline 30. & Cito Test Strep A & Pharmasco Ltd & 162.50 & 131.87 & 0.23 & 150.25 & 1.40 \\
\hline 31. & Test to determine menopause & Pharmasco Ltd & 35.00 & 29.40 & 0.19 & 32.20 & 0.30 \\
\hline 32. & $\begin{array}{l}\text { Test to determine markers of the blood coagula- } \\
\text { tion system }\end{array}$ & Response Biomedical Corp. & 180.00 & 165.00 & 0.09 & 172.50 & 1.60 \\
\hline 33. & $\begin{array}{l}\text { Test to measure the level of cholesterol, } \\
\text { uric acid in the blood }\end{array}$ & Wellion & 600.00 & 389.00 & 0.54 & 479.66 & 4.47 \\
\hline 34. & Test to determine the $\mathrm{pH}$ of urine № 50 & TOV Norma & 30.00 & 20.00 & 0.50 & 25.00 & 0.23 \\
\hline 35. & Test to determine ovulation & Atlas Link Technology Co., Ltd & 284.00 & 164.78 & 0.72 & 224.39 & 2.09 \\
\hline 36. & Rab Test (RabiesAg) & Quicking Biotech Co., Ltd & 254.00 & 240.00 & 0.06 & 247.00 & 2.30 \\
\hline
\end{tabular}


Conflicts of interest: authors have no conflict of interest to declare. Конфрлікт інтересів: відсутній.

Information about authors:

Brytanova T. S., PhD, Teaching Assistant of the Department of Management and Pharmacy Economics, Zaporizhzhia State Medical University, Ukraine.

ORCID ID: 0000-0003-1805-4552

Samko A. V., PhD, Senior Lecturer of the Department of Management and Pharmacy Economics, Zaporizhzhia State Medical University, Ukraine.

ORCID ID: 0000-0002-3182-5588

Knysh Ye. H., Dr. hab., Professor, Head of the Department of Management and Pharmacy Economics, Zaporizhzhia State Medical University, Ukraine. ORCID ID: 0000-0002-8002-6117

Відомості про авторів:

Британова Т. С., канд. фрарм. наук, асистент каф. управління і економіки фармації, Запорізький державний медичний університет, Україна.

Самко А. В., канд. фарм. наук, старший викладач каф. управління і економіки фрармації, Запорізький державний медичний університет, Україна.

Книш Є. Г., д-р фарм. наук, профресор, зав. каф. управління і економіки фармації, Запорізький державний медичний університет, Україна.

Сведения об авторах:

Британова Т. С., канд. фарм. наук, ассистент каф. управления и экономики фармации, Запорожский государственный медицинский университет, Украина.

Самко А. В., канд. фарм. наук, старший преподаватель каф. управления и экономики фармации, Запорожский государственный медицинский университет, Украина.
Кныш Е. Г., д-р фарм. наук, профессор, зав. каф. управления и экономики фрармации, Запорожский государственный медицинский университет, Украина.

\section{References}

[1] Shirin, H., Bruck, R., Kenet, G., Krepel, Z., Wardi, J., Reif, S., Zaidel, L., Geva, D., Avni, Y., \& Halpern, Z. (1999). Evaluation of a new immunochromatographic test for Helicobacter pylori IgG antibodies in elderly symptomatic patients. Journal of gastroenterology, 34(1), 7-10. https://doi.org/10.1007/s005350050209

[2] Tabletki.ua. https://tabletki.ua/uk/

[3] Apteka „Apteka nyzkykh tsin. https://www.aptekanizkihcen.ual

[4] Apteka „Narodna apteka». https://www.apteki.zp.ual

[5] Apteka "Zhyva voda”. https://shop.av.zp.ual

[6] Apteka „Bazhaiemo zdorovia”. https://apteka.net.ua/

[7] Apteka "Dobroho dnia". https://www.add.ua/

[8] Apteka "1 Sotsialna apteka”. https://1sa.com.ual

[9] Apteka "Med-Servys". https://online-apteka.com.ua

[10] State Service of Ukraine on Medicines and Drugs Control. (n.d.). Derzhavnyi reiestr medychnoi tekhniky ta vyrobiv medychnoho pryznachennia [State Register of Medical Equipment and Medical Devices]. https://www.dls.gov.ua/en/medical-products/state-register-of-medical-equipment-and-medical-devices/

[11] Shchotyzhnevyk Apteka [Weekly Pharmacy]. https://www.apteka.ual

[12] Hromovyk, B. P. (2002). Kharakterystyka osnovnykh metodyk vyznachennia konkurentospromozhnosti likarskykh zasobiv [Characteristics of the main methods of determining the competitiveness of drugs]. Farmatsevtychnyi zhurnal, (3), 7-11. [in Ukrainian].

[13] State Statistics Service of Ukraine (2016). Statystychnyi shchorichnyk Ukrainy [Statistical Yearbook of Ukraine for 2015]. Kyiv: Tekhnika. [in Ukrainian].

[14] Mnushko, Z. M., \& Popova, Yu. V. (2007). Metodyky otsinky rivnia konkurentospromozhnosti likarskykh preparativ: metodychni rekomendatsii [Methods of assessing the level of competitiveness of medicinal products]. Kharkiv: NFaU. [in Ukrainian].

[15] Derzhavna sluzhba statystyky Ukrainy [State Statistics Service of Ukraine]. http://www.ukrstat.gov.ual 